\title{
LABORATORY DIAGNOSIS OF EPIDEMIC KERATOCONJUNCTIVITIS
}

\author{
Eleanor J. Bell, Karen W. Martin and Constance A. C. Ross \\ The Regional Virus Laboratory, Ruchill Hospital, Glasgow
}

IN the western world epidemic keratoconjunctivitis (EKC) has been reported in shipyard workers and in patients attending ophthalmological clinics; it is a disease of both public health and economic importance. Adenovirus type 8 has been the agent most frequently associated with epidemic and sporadic cases of EKC (Jawetz, 1959; Mordhorst and Kjer, 1961 ; Béládi et al., 1963-64; Nász et al., 1963-64a). This virus is one of the most difficult of the adenovirus group to propagate in cell cultures. During the 1956 outbreak of EKC in the West of Scotland, Sommerville (1958) failed to isolate this virus from conjunctival swabs inoculated into HeLa cultures; the evidence that adenovirus 8 was the aetiological agent was based on the finding of neutralising antibody in the patients' sera. The occurrence of another large outbreak of EKC in this region during the autumn of 1967 gave us the opportunity to compare the value of various laboratory methods of diagnosis.

\section{MATERIALS AND METHODS}

Virus isolation. Conjunctival scrapings, collected in virus transport medium (Grist et al., 1966) were obtained from 186 patients presenting with conjunctivitis or keratoconjunctivitis in the early stage of illness; $0.2 \mathrm{ml}$ of the suspension of scrapings was inoculated into each tube of cell culture tested.

The cell cultures used were primary human amnion (AMN), primary human embryo kidney (HEK), HeLa, and secondary rhesus monkey kidney (RMK); all were maintained in Eagle's basal medium, supplemented in the case of HeLa with 2 per cent. rabbit serum and in the case of AMN, HEK and RMK with 0.5 per cent. foetal bovine serum. Examination of inoculated cultures was continued for 28 days unless specific virus degeneration had occurred. Before they were finally discarded as negative, all the cultures were tested for haemagglutination with human group-O erythrocytes at $37^{\circ} \mathrm{C}$ (Lengyel and Nász, 1964-65). Viruses isolated were identified by neutralisation tests using type-specific rabbit antisera.

Serological investigations. Paired sera were available for study from 137 of 186 patients, the first specimen being collected early in the illness and the second specimen generally 2-3 wk later. The sera were examined by complement fixation (CF) and haemagglutination inhibition (HI) tests.

CF tests were carried out as described by Grist et al. with the group-specific antigen employed in our laboratory for routine diagnostic tests of all suspected adenovirus infections; this antigen was prepared from human embryo lung cell cultures infected with adenovirus type 5 , inactivated at $56^{\circ} \mathrm{C}$ for $30 \mathrm{~min}$.

For HI tests, acute and convalescent phase sera were neither heat-inactivated nor otherwise treated before use. Preliminary results using kaolin-absorbed and untreated sera in parallel indicated that satisfactory results could be obtained with untreated sera. Antigen was prepared from human embryo kidney cultures infected with adenovirus 8 ; after complete 
degeneration of the cell layers, the cultures were twice frozen and thawed, and the pooled material was divided into convenient volumes and stored at $-20^{\circ} \mathrm{C}$ until it was needed. HI tests were carried out using " Microtiter" methods (unit volume $0.025 \mathrm{ml}$ ) with 4 haemagglutinating units of antigen. Serum-antigen mixtures were incubated for $1 \mathrm{hr}$ at room temperature before the addition of human group-O erythrocytes and further incubated at $37^{\circ} \mathrm{C}$ for $1 \mathrm{hr}$. The serum titre was taken as the highest dilution showing complete inhibition of haemagglutination. All serum titres were expressed as reciprocals.

\section{RESULTS}

Virus isolation. Of the 186 patients investigated, adenovirus type 8 was recovered from 57, type 3 from 11, type 7 from 4 and type 10 from 2; one patient yielded an untyped adenovirus and 6 patients herpes simplex virus. Initially specimens of conjunctival scrapings were inoculated into cultures of human amnion, HeLa and rhesus monkey kidney. A comparison of virus isolations in these three systems is shown in table I. Since amnion proved superior to the other two tissues for the isolation of adenovirus 8 , all subsequent

TABLE I

Viruses isolated from 106 samples of conjunctival scrapings tested in three cell cultures

\begin{tabular}{|c|c|c|c|c|c|c|}
\hline \multirow{4}{*}{ Cell culture } & \multicolumn{5}{|c|}{ Adenovirus isolations } & \multirow{4}{*}{$\begin{array}{l}\text { Herpes simplex } \\
\text { virus isolations }\end{array}$} \\
\hline & \multirow{3}{*}{$\begin{array}{c}\text { Number } \\
\text { of } \\
\text { patients }\end{array}$} & \multicolumn{2}{|l|}{ Type 8} & & \multirow{3}{*}{$\begin{array}{l}\text { Other } \\
\text { types }\end{array}$} & \\
\hline & & \multirow{2}{*}{$\begin{array}{c}\text { Percentage } \\
\text { of } \\
\text { patients }\end{array}$} & \multicolumn{2}{|c|}{$\begin{array}{l}\text { Days to cyto- } \\
\text { pathic effect }\end{array}$} & & \\
\hline & & & Range & Mean & & \\
\hline Human amnion & 34 & 32 & $4-26$ & 14 & 3 & 4 \\
\hline HeLa cells & 5 & 5 & $*$ & * & 2 & 4 \\
\hline Rhesus monkey kidney & 4 & 4 & $8-25$ & 13 & 2 & 0 \\
\hline
\end{tabular}

* Blind passage required.

specimens were inoculated into cultures of human amnion and also into human embryo kidney, a supply of which became available at this time. Table II summarises the comparative isolation of viruses in these two tissues. As expected, embryo kidney cultures proved superior to amnion not only in the percentage isolations of adenovirus 8 but also in the average length of time required for isolation.

Serological investigations. Of the 38 patients from whom adenovirus 8 was isolated 37 exhibited a four-fold or greater rise in HI antibody titre (table III); only 25 of these had a rise in CF antibody titre. Other workers have also found that the CF response in some patients is either not detectable or is delayed (Sommerville; Mordhorst and Kjer). A rise in HI titre was also detected in 
TABLE II

Viruses isolated from 89 samples of conjunctival scrapings tested in two cell cultures

\begin{tabular}{|c|c|c|c|c|c|c|}
\hline \multirow{4}{*}{ Cell culture } & \multicolumn{5}{|c|}{ Adenovirus isolations } & \multirow{4}{*}{$\begin{array}{c}\text { Herpes simplex } \\
\text { isolations }\end{array}$} \\
\hline & \multirow{3}{*}{$\begin{array}{c}\text { Number } \\
\text { of } \\
\text { patients }\end{array}$} & \multicolumn{2}{|l|}{ Type 8} & & \multirow{3}{*}{$\begin{array}{l}\text { Other } \\
\text { types }\end{array}$} & \\
\hline & & \multirow{2}{*}{$\begin{array}{c}\text { Percentage } \\
\text { of } \\
\text { patients }\end{array}$} & \multicolumn{2}{|c|}{$\begin{array}{l}\text { Days to cyto- } \\
\text { pathic effect }\end{array}$} & & \\
\hline & & & Range & Mean & & \\
\hline Human embryo kidney & 29 & 33 & $4-13$ & 8 & 11 & 2 \\
\hline Human amnion & 22 & 25 & $4-26$ & 16 & 9 & 2 \\
\hline
\end{tabular}

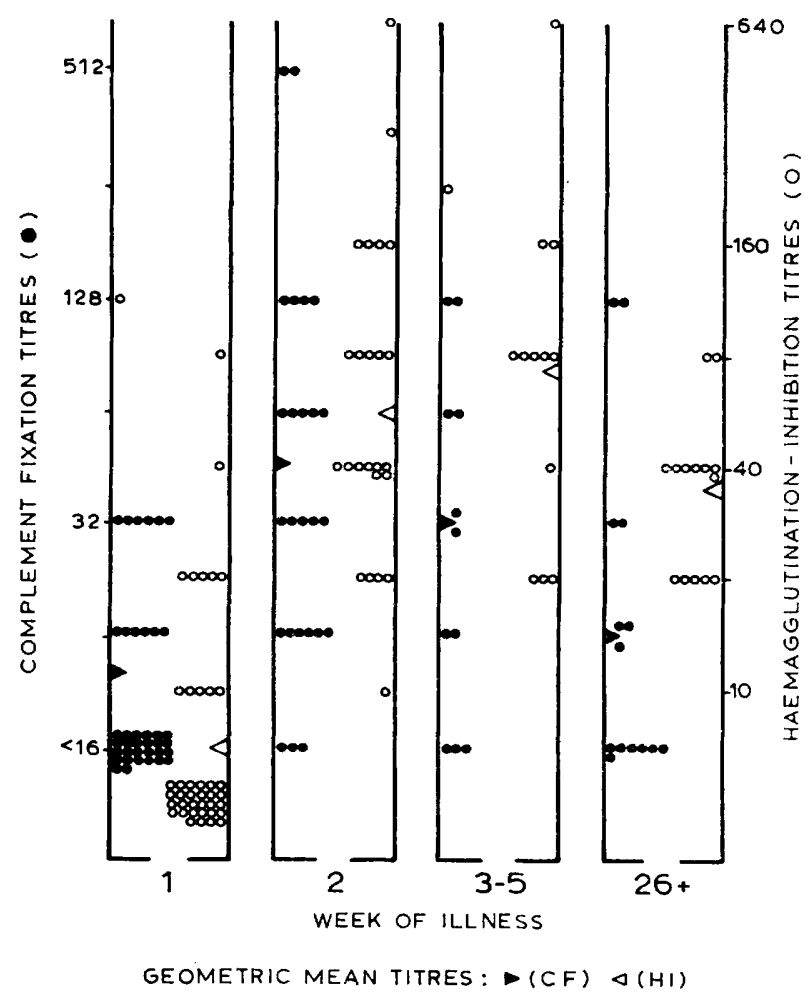

FIGURE.-Complement fixation and haemagglutination-inhibition antibody titres of 38 patients from whom adenovirus type 8 was isolated. 


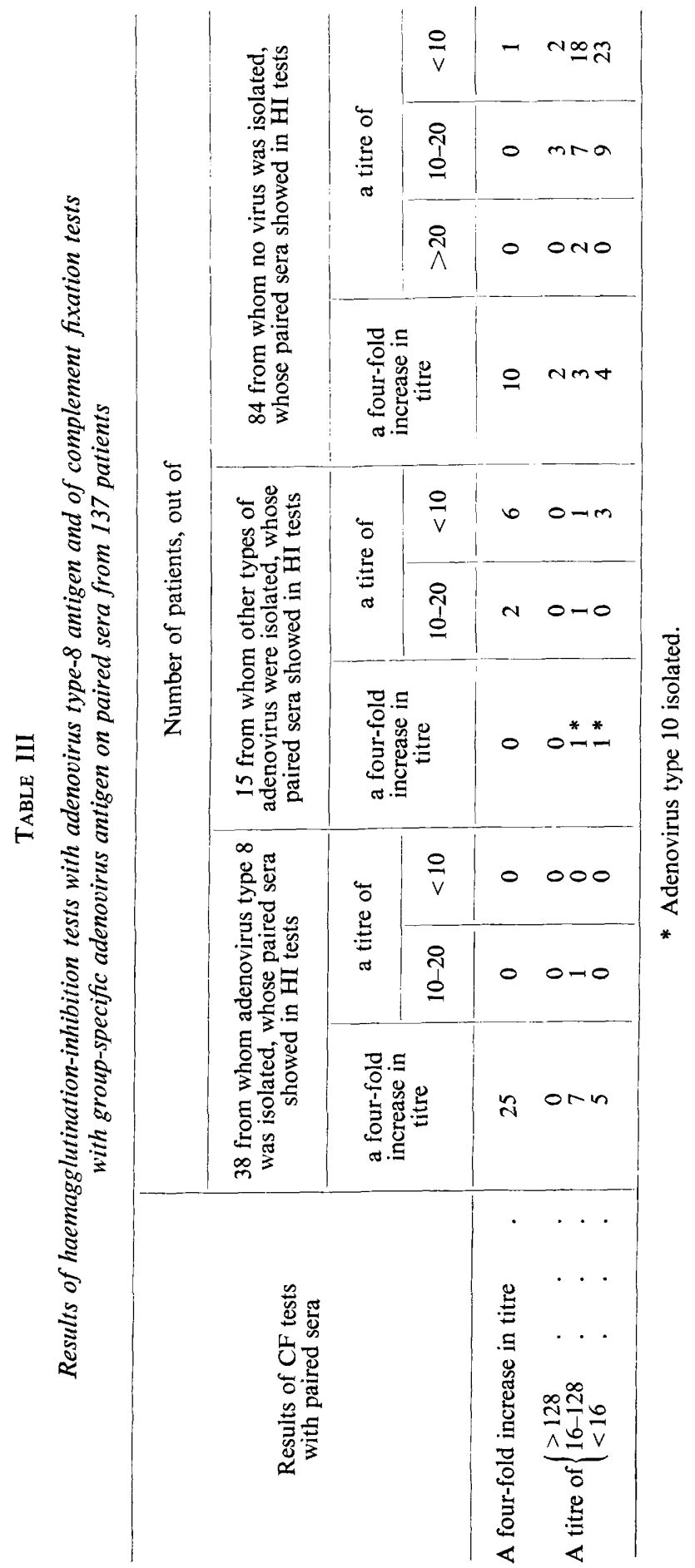


the sera of the two patients with adenovirus 10 infection. This result was not unexpected since cross-reactions in the HI test between adenoviruses 8,9 and 10 are known to exist (Nász et al., 1963-64b). Little or no serological crossreactivity in $\mathrm{HI}$ tests was observed in those patients from whom other adenovirus types or herpes simplex virus were isolated. On the basis of this correlation between $\mathrm{HI}$ results and adenovirus- 8 isolations, the finding of a rise in HI titre in 19 and high titres (160) in 2 patients, from whom no adenovirus was isolated, suggested a presumptive diagnosis of adenovirus- 8 infection; no rising or high CF titres were detected in 9 of these 21 .

In the 38 patients from whom adenovirus 8 was isolated, $\mathrm{HI}$ antibodies reached higher titres than CF during early convalescence (see figure). The persistence of the antibody levels after infection was studied in 14 of the patients from whom we received third specimens of sera 6-7 mth after onset of illness. A mean titre of 40 was detectable in the $\mathrm{HI}$ test compared with a titre of 16 in the CF test. This suggested that for adenovirus 8 there is a more rapid fall in $\mathrm{CF}$ than in $\mathrm{HI}$ antibody titres.

\section{Discussion}

In this series of 186 patients with conjunctivitis or keratoconjunctivitis, virus was recovered from 81 ( 43 per cent.) of which 57 were adenovirus type 8 . Comparison of 4 different cell culture systems for the isolation of adenovirus 8 showed that human embryo kidney and human amnion were more sensitive than either HeLa or rhesus monkey kidney. Although human embryo kidney is the optimal tissue for the study of an outbreak of EKC, it is usually difficult to obtain; nevertheless virus laboratories can perform a useful service in such investigations by using the readily available human amnion cultures.

Nász et al. (1963-64a) found that HI tests were as good, if not better, than $\mathrm{CF}$ and neutralisation tests for the serological diagnosis of epidemic keratoconjunctivitis. Although there are cross-reactions between adenoviruses 8,9 and 10 (Nász et al., 1963-64b; Jancsó, 1965-66) the HI test in the present series made a presumptive diagnosis of adenovirus- 8 infection possible in an additional 21 patients from whom no virus was isolated. The use of human group-O erythrocytes rather than the more frequently used rat erythrocytes, which tend to agglutinate spontaneously (Rosen, 1960), made the HI test, in our experience, more convenient to perform.

In common with other workers (Nász et al., 1963-64a), we found that in patients from whom adenovirus 8 was isolated, $\mathrm{HI}$ antibodies reached higher titres and persisted longer than CF group-specific antibodies.

\section{SUMMARY}

During an outbreak of epidemic keratoconjunctivitis in 1967, adenovirus type 8 was recovered from 57 of 186 patients investigated. Primary human embryo kidney and human amnion cell cultures were more efficient than either HeLa or rhesus monkey kidney cultures for isolation of this virus. Serological tests detected 21 additional infections. Haemagglutination inhibition, using 
human group-O cells, provided a convenient technique for detecting adenovirus-8 infections.

We wish to thank Dr J. Dudgeon of Glasgow Eye Infirmary for faithful collection of specimens; also Dr C. Patricia M. Bradstreet, Standards Laboratory for Serological Reagents, Colindale, London, for supplies of adenovirus typing sera and Mrs M. Sneddon, Miss M. Walker and Miss R. Rodger for valuable technical assistance.

\section{REFERENCES}

Béládi, Ilona, KaháN, Á., KuKÁN, 1963-64. Acta microbiol. hung., 10, 59. Esther, Mucsi, Ilona, AND PÁPAI, I.

Grist, N. R., Ross, Constance A. C., $1966 . \quad$ Diagnostic methods in clinical viroBell, Eleanor J., and Stott, E. J.

JANCSÓ, AGNes . . . . . . . . . . 1965-66. Acta microbiol. hung., 12, 207. JAWETZ, E. . . . . . . . . . $1959 . \quad$ Br. Med. J., 1, 873.

LENGYel, ANNA, AND NÁsZ, I. . . . 1964-65. Acta microbiol. hung., 11, 105. Mordhorst, C. H., AND KJER, P. . . 1961. Acta ophth., 39, 974.

Nász, I., Kulcsár, Gizella, Dán, P., 1963-64a. Acta microbiol. hung., 10, 35. Lengyel, ANNA, AND Cserba, IdA

NÁsz, I., Lengyel, ANNA, DÁN, P., AND 1963-64b. Ibid., 10, 379. Kulcsár, Gisella

Rosen, L. . . . . . . . . . 1960. Amer. J. Hyg., 71, 120.

Sommerville, R. G. . . . . . . 1958. J. Hyg., Camb., 56, 101. 